Original Article

\title{
Cross-cultural adaptation of the 12-item Örebro musculoskeletal screening questionnaire to Japanese (ÖMSQ-12-J), reliability and clinicians' impressions for practicality
}

\author{
Hiroshi Takasaki, RPT, BSc, MSc, PhD ${ }^{1)^{*}}$, Charles Philip Gabel, RPT, BSc, MSc, PhD ${ }^{2}$ \\ 1) Division of Physical Therapy, Saitama Prefectural University: 820 Sannomiya, Koshigaya, \\ Saitama 343-8540, Japan \\ 2) Coolum Physiotherapy Clinic, Australia
}

\begin{abstract}
Purpose] To translate and culturally adapt the Örebro Musculoskeletal Screening Questionnaire (ÖMSQ-12) into Japanese (ÖMSQ-12-J), and to preliminarily investigate practicality from the clinicians' perspectives, and determine inter-session reliability. [Subjects and Methods] This study included four phases: cross-cultural adaptation (Phases 1-2); survey among 14 clinicians (two medical doctors and 12 physiotherapists) about the practicality of using the questionnaire in six perspectives (speed of evaluation/treatment; capacity to detect patients with yellow flags; attitude towards management with bio-psycho-social perspectives; quality of evaluation/treatment; considerations of communications with patients at history-taking, physical assessments and interventions; and general clinical usefulness) based on their experiences with patients (Phase 3); and investigation of inter-session reliability among 50 patients with musculoskeletal disorders (Phase 4). [Results] The ÖMSQ-12-J was developed in Phases 1-2 using the recommended international guidelines for cultural adaptation and translation. In Phase 3, most responses were in the 3-positive options (35.7-78.6\%). In Phase 4, the Intraclass Correlation Coefficient for each item ranged from $0.71-0.99$ and 0.92 for the total score. [Conclusion] This study developed the ÖMSQ-12-J, which has preliminary evidence of good practicality and moderate-strong inter-session reliability. Further investigation is required to determine the predictive and prognostic capacity within a problematic musculoskeletal Japanese population.

Key words: Bio-psycho-social, Prognostic tool, Screening
\end{abstract}

(This article was submitted Apr. 12, 2017, and was accepted May 25, 2017)

\section{INTRODUCTION}

Musculoskeletal disorders place an enormous social and economic burden on the affected individuals' health and the social care systems ${ }^{1,2)}$. The average effect of a management, treatment or intervention is modest when patients are within a heterogeneous group and a stratified model of care is used to determine the magnitude of an intervention ${ }^{3,4)}$. This stratified treatment approach has been demonstrated as effective in low back pain (LBP) by researchers where a prognostic screening tool is used - such as the Acute Low back Pain Screening Questionnaire (ALBPSQ) ${ }^{5,6}$ ) or its adapted and evolved version, the Örebro Musculoskeletal Pain Questionnaire (ÖMPQ) ${ }^{7}$, and the STarT Back Screening Tool (SBST) ${ }^{8)}$. These tools have demonstrated a better treatment effect than a non-stratified approach ${ }^{9},{ }^{10}$. Other similar tools have been previously used in LBP populations ${ }^{5,11)}$ but only a limited number of tools are applicable to a general musculoskeletal population ${ }^{12,13)}$. Consequently, there is an increasing and recognized need to either validate existing screening tools or further develop new

*Corresponding author. Hiroshi Takasaki (E-mail: takasaki-hiroshi@spu.ac.jp)

(C2017 The Society of Physical Therapy Science. Published by IPEC Inc.

(c) (1) $\odot$ This is an open-access article distributed under the terms of the Creative Commons Attribution Non-Commercial No Deriva-

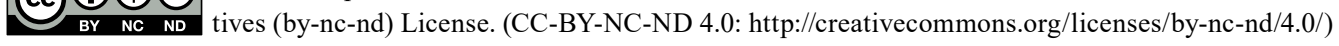


tools that help to identify individuals with a high risk of poor prognosis ${ }^{3)}$.

Tools such as the ALBPSQ and SBST are recognized for their prognostic screening capacity in LBP populations. However, being specific to LBP has limitations for generalizability to other musculoskeletal disorders. To resolve this conundrum and broaden its application to provide generalizability, the ALBPSQ was modified to the ÖMPQ through word changes. Although changing words was critiqued as unsatisfactory ${ }^{14)}$ as it did not provide population specific validation; however, the ÖMPQ was shown to be effective in predicting the high risk of chronicity and prolonged recovery ${ }^{15-17)}$. The ÖMPQ was subsequently shortened to the 10-item ÖMPQ (ÖMPQ-10) to improve practicality. This process did not follow a robust quantitative process but a subjective reduction methodology and therefore the ensuing validation process has also been criticized as it did not use a general musculoskeletal population. Additionally, the selected items in the ÖMPQ-10 demonstrated a correlation with the original full-length questionnaire $(r=0.92)$ that was not shown to exceed 10 items randomly selected $(r=0.94)^{7,12}$. Though there is a need for continuity and a following of the principle of parsimony, these dilemmas and short comings in the ÖMPQ could only be overcome through a retracing of the original tool's development and the provisions of modification in a step wise process ${ }^{12-14}$. This process developed and initially validated the modified original-ÖMPQ in a LBP population ${ }^{14)}$, then broadened its application further and validated the tool for all musculoskeletal disorders by addressing the existing concerns ${ }^{13}$. Finally, to improve practicality and reduce the burden on patients, clinicians and researchers, a 12-item version (ÖMSQ-12) was developed through a robust and combined qualitative and quantitative process ${ }^{18)}$ that produced a shortened tool which correlated $(\mathrm{r}=0.97)$ with the original 21 -item questionnaire ${ }^{12}$.

To date there has been no Japanese version of any of the ÖMPQ, the ÖMPQ-10 and ÖMSQ-12. The researchers of this study selected the ÖMSQ-12 in preference to the ÖMPQ-10 for translation and cross-cultural adaptation due to its sound methodological development, brevity, higher correlation with the original full length 21 -item version, reported practicality and applicability to general musculoskeletal populations. However, it is unknown if this practicality is retained from the clinicians' qualitative perspectives and if the intersession reliability of each item and the total tool score is satisfactory and high.

Consequently, the purpose of this study was to develop a Japanese version of the ÖMSQ-12 (ÖMSQ-12-J) through the translation and cultural adaptation process; to preliminarily investigate the tool's practicality from the clinicians' perspectives; and to determine the intersession reliability of each item and the tool's total score. This study would then produce a Japanese specific screening musculoskeletal questionnaire, the ÖMSQ-12-J, that would form a foundation in the development of musculoskeletal screening for Japanese society. From this preliminary process, further research that is beyond the scope of this pilot and translational study may be conducted to determine and validate the clinical predictive capacity from longitudinal investigations and the ability to predict future problems such as work disability and recovery time through the identification of yellow flag signs ${ }^{6,19)}$.

\section{SUBJECTS AND METHODS}

The study included four phases. Phase 1 was to undertake cross-cultural adaptation of the ÖMSQ-12 into Japanese and develop a pre-final draft. Phase 2 was to assess the comprehensibility of the pre-final draft using patients with musculoskeletal disorders and develop a final draft. Phase 3 was to preliminarily investigate practicality using medical doctors and physiotherapists. Phase 4 was to investigate intersession reliability of each items using patients with musculoskeletal disorders. The ethical clearance of this study was approved by the Institutional Review Board of the Saitama Prefectural University (27078).

In Phase 1, the translation and cultural adaptation process of the ÖMSQ-12 was consented by the developing authors and followed the guideline proposed by Beaton et $\mathrm{al}^{20)}$. The ÖMSQ-12 was translated from English into Japanese by two independent non-medical translators who were bilingual in English and Japanese. The purposes of this study were known for one translator and blinded for the other. A reconciliation meeting was held and a consensus version of the forward-translation developed with the two translators and a study coordinator. The adaptations and reasons are summarized in the Appendix 1. The consensus version of the ÖMSQ-12-J was then back-translated into English by two physiotherapists who were bilingual in English and Japanese. The two back-translations were reviewed, a consensus version obtained and forwarded to the developing authors who accepted all items.

In Phase 2, the pre-final draft of the ÖMSQ-12-J was pilot-tested on a convenience sample of 30 outpatients with musculoskeletal disorder undertaking physiotherapy in a primary care center (age range, 20-79 years; symptoms duration range, 2 days-30 years; gender, 17 females and 13 males). The patients were asked to document any ambiguity in meaning during the questionnaire administration. No ambiguity of meaning was reported and the pre-final ÖMSQ-12-J draft became the final draft without further modification. The ÖMSQ-12-J (Appendix 2) was reported as easy to understand for individuals over 20 years of age.

In Phase 3 to preliminarily investigate practicality of the ÖMSQ-12-J, clinicians who were credentialed in Mechanical Diagnosis and Therapy (MDT), which is a conservative treatment approach for musculoskeletal disorders, were included. History taking in MDT is systematic and comprehensive, and credentialed MDT clinicians include a strong consideration of the bio-psycho-social perspectives within their management strategies ${ }^{21)}$ and have standardized clinical decisions making skills $^{22-24)}$. Consequently, it was considered that the MDT practitioners' opinions on the practicality of the ÖMSQ-12-J would reliably reflect the questionnaires' performance in the clinical setting. Forty-six credentialed MDT clinicians listed as potential research collaborators in the McKenzie Institute International Japan Branch were contacted and a sample of 
convenience with 14 clinicians (two medical doctors and 12 physiotherapists) agreed to participate in the anonymous survey.

A structured survey was conducted to gain clinicians' opinions towards the practicality of the ÖMSQ-12-J based on their immediate experience of using the questionnaire with their patients. The survey included a total of six items on: 1) speed of evaluation/treatment; 2) possibility in detecting patients with yellow flag signs; 3 ) attitudes towards management from the bio-psycho-social perspectives; 4) quality of evaluation/treatment; 5) considerations of patient communications with history-taking, physical assessment and interventions; and 6) usefulness of the ÖMSQ-12-J. A 7-point Likert scale was used to assess the effect of the questionnaire on the six practicality survey items with three positive (slightly, very or extremely increased), three negative (slightly, very or extremely decreased) and a neutral central reference of 'Neither' being no positive or negative effect.

In Phase 4, consecutive outpatients $(n=50)$ were included from a sample of convenience with musculoskeletal disorders referred to physiotherapy in a primary care center (Saitama, Japan). A priori sample size estimation was based on a confidence interval approach for the intraclass correlation coefficient (ICC ${ }^{25-27)}$ using the PASS 14 Power Analysis and Sample Size Software 2015 (NCSS, LLC, Kaysville, Utah, USA). A sample of 48 patients who were each measured two times produced a two-sided $95 \%$ confidence interval $(95 \% \mathrm{CI})$ with a width of 0.30 when the estimated ICC was 0.70 . Thus, the sample size was set at 50 in this study. The patients provided their demographic details, predominant symptoms location and the duration. They also completed the P4 pain intensity measure, a reliable and validated 4-item questionnaire with four 0-10 numerical rating scales related to pain intensity (0: no pain, 40: the highest possible pain level) in the morning, afternoon, evening and with activity ${ }^{28}$. The patients also completed the final draft ÖMSQ-12-J twice on separate days before treatment/management was initiated. At follow-up, all patients were blinded to their initial ÖMSQ-12-J responses.

Regarding statistical analysis, descriptive analysis was used to summarize the clinicians' response to the Phase-3 ÖMSQ12-J practicality survey and the patient demographics from Phase 4. Intersession reliability of each of the ÖMSQ-12-J items was assessed with the ICC with Two-way Random Model $\left(\operatorname{ICC}_{(2,1)}\right)$. Evaluation criteria for the $\operatorname{ICC}_{(2,1)}$ were: $\leq 0.40=$ weak, $0.41-0.74=$ moderate, $\geq 0.75=$ strong $^{29}$ ).

\section{RESULTS}

The summary of the clinicians' responses from Phase- 3 practicality are presented in Table 1 . The majority of the clinicians had positive opinions towards the practicality of the ÖMSQ-12-J.

The patient demographics are summarized in Table 2. The mean (SD) intersession reliability interval for the two ÖMSQ12-J administrations was 2.6 (2.9) days. The $\mathrm{ICC}_{(2,1)}$ value for each of the 12 items was rated as moderate to strong $(0.71-0.99)$ (Table 3). The $\operatorname{ICC}_{(2,1)}(95 \%$ CIs) for the total score was $0.92(0.86-0.96)$.

\section{DISCUSSION}

In this study, the ÖMSQ-12-J, a Japanese version of the ÖMSQ-12, was developed and assessed for intersession reliability in a musculoskeletal population, and the clinicians' impressions' for practicality were also examined. This study will consequently form a foundation for further investigating the prognostic ability of the ÖMSQ-12-J in Japanese society and its capacity to serve as a means of identification of yellow flag signs. Such studies may be completed through a longitudinal assessment process that can be conducted to determine and validate the clinical predictive capacity and the ability to predict future problems that may include but not be limited to work disability and recovery time.

From the clinicians reported perspective, the majority had positive opinions the ÖMSQ-12-J and its practicality. They felt its use would not interfere with a clinician's assessment and management. Furthermore, 50\% of clinicians felt the ÖMSQ12-J increased their capacity to detect bio-psycho-social yellow flag signs. These preliminary findings are important in relation to potentially encouraging clinicians to routinely use the ÖMSQ-12-J. The ÖMSQ-12-J includes items related to a variety of bio-psycho-social factors including anxiety, depression, hopefulness, kinesiophobia, dissatisfaction and selfefficacy. Consequently, it may be used not only as a prognostic or screening tool but potentially also as a reminder of the importance of bio-psycho-social perspectives and which of these may need to be further investigated more comprehensively by referral to other professionals or construct specific questionnaires.

Future research will be initially focused in at least two directions. Firstly, the comparability of the ÖMSQ-12-J with other prognostic tools, in relation to the investigation of external validity such as concurrent validity. Fuhro et al. ${ }^{30)}$ have demonstrated the concurrent validity of the ÖMSQ-10 and the SBST in the Brazilian Portuguese version. The second is the longitudinal analysis to determine the ÖMSQ-12-J cut-off values in Japanese society. Attitudes toward absenteeism in Japan are likely to be different from that of Western cultures and the definition of recovery would also be different. A study with a large sample of wait-and-see participants would be required to determine the cut-off values. However, the collection of such data may be difficult. This will require national musculoskeletal research networks in which large sample sizes must be identified and recruited. The preliminary finding of positive clinicians attitudes toward the ÖMSQ-12-J practicality may help the development of such national research networks, which is a research priory for non-pharmacological therapies addressing common musculoskeletal problems ${ }^{4)}$.

A strength of this study and ÖMSQ-12-J in comparison to the back focused SBST and ALBPSQ, and by consequence of 
Table 1. Summary of 14 clinicians' responses towards the practicality of the ÖMSQ-12-J

\begin{tabular}{|c|c|c|}
\hline Item (No. Description) & \multicolumn{2}{|c|}{ Responses n (\%) } \\
\hline \multirow{6}{*}{$\begin{array}{l}\text { 1. Has your general } \\
\text { evaluation/treatment } \\
\text { speed been increased } \\
\text { by using the ÖMSQ- } \\
12-\mathrm{J} \text { ? }\end{array}$} & Extremely increased & $0(0)$ \\
\hline & Very increased & $1(7.1)$ \\
\hline & Slightly increased & $4(28.6)$ \\
\hline & Neither & $6(42.9)$ \\
\hline & Slightly decreased & $2(14.3)$ \\
\hline & Very decreased & $0(0)$ \\
\hline \multirow{8}{*}{$\begin{array}{l}\text { 2. Has the possibil- } \\
\text { ity to detect patients } \\
\text { with yellow flags been } \\
\text { increased by using the } \\
\text { ÖMSQ-12-J? }\end{array}$} & Extremely decreased & $1(7.1)$ \\
\hline & Extremely increased & $0(0)$ \\
\hline & Very increased & $4(28.6)$ \\
\hline & Slightly increased & $3(21.4)$ \\
\hline & Neither & $7(50.0)$ \\
\hline & Slightly decreased & $0(0)$ \\
\hline & Very decreased & $0(0)$ \\
\hline & Extremely decreased & $0(0)$ \\
\hline \multirow{7}{*}{$\begin{array}{l}\text { 3. Has your attitude } \\
\text { towards management } \\
\text { with bio-psycho-social } \\
\text { perspectives been } \\
\text { enhanced by using the } \\
\text { ÖMSQ-12-J? }\end{array}$} & Extremely enhanced & $0(0)$ \\
\hline & Very enhanced & $4(28.6)$ \\
\hline & Slightly enhanced & $7(50.0)$ \\
\hline & Neither & $3(21.4)$ \\
\hline & Slightly degraded & $0(0)$ \\
\hline & Very degraded & $0(0)$ \\
\hline & Extremely degraded & $0(0)$ \\
\hline \multirow{7}{*}{$\begin{array}{l}\text { 4. Has the quality of } \\
\text { your evaluation/treat- } \\
\text { ment been increased by } \\
\text { using the ÖMSQ-12-J? }\end{array}$} & Extremely increased & $1(7.1)$ \\
\hline & Very increased & $2(14.3)$ \\
\hline & Slightly increased & $7(50.0)$ \\
\hline & Neither & $4(28.6)$ \\
\hline & Slightly decreased & $0(0)$ \\
\hline & Very decreased & $0(0)$ \\
\hline & Extremely decreased & $0(0)$ \\
\hline \multirow{7}{*}{$\begin{array}{l}\text { 5. Has your consider- } \\
\text { ations of communica- } \\
\text { tions with patients at } \\
\text { history-taking, physi- } \\
\text { cal assessments and } \\
\text { interventions been } \\
\text { increased by using the } \\
\text { ÖMSQ-12-J? }\end{array}$} & Extremely increased & $0(0)$ \\
\hline & Very increased & $5(35.7)$ \\
\hline & Slightly increased & $5(35.7)$ \\
\hline & Neither & $4(28.6)$ \\
\hline & Slightly decreased & $0(0)$ \\
\hline & Very decreased & $0(0)$ \\
\hline & Extremely decreased & $0(0)$ \\
\hline \multirow{7}{*}{$\begin{array}{l}\text { 6. Do you think the } \\
\text { ÖMSQ-12-J is useful? }\end{array}$} & Extremely useful & $1(7.1)$ \\
\hline & Very useful & $4(28.6)$ \\
\hline & Slightly useful & $5(35.7)$ \\
\hline & Neither & $3(21.4)$ \\
\hline & Slightly non-useful & $0(0)$ \\
\hline & Very non-useful & $1(7.1)$ \\
\hline & Extremely non-useful & $0(0)$ \\
\hline
\end{tabular}

Table 2. Participants demographics

\begin{tabular}{llc}
\hline Variables & & Values \\
\hline Age (years) & & $25.9 \pm 11.3$ \\
& Female & $23(46)$ \\
Gender, No. (\%) & Male & $27(54)$ \\
P4 (0-40) & & $12.4 \pm 9.1$ \\
Symptom duration (months) & $40.1 \pm 84.3$ \\
& $<1$ week & $0(0)$ \\
Phase of symptom & 1 week -3 months & $15(30)$ \\
duration, No. (\%) & $>3$ months & $35(70)$ \\
& Neck/head/upper back & $4(8)$ \\
& Shoulder & $5(10)$ \\
& Elbow & $3(6)$ \\
Painful body part, & Wrist/finger & $5(10)$ \\
No. (\%) & Lower back/pelvis & $11(22)$ \\
& Hip & $3(6)$ \\
& Knee & $14(28)$ \\
& Ankle/foot & $5(10)$ \\
\hline
\end{tabular}

Table 3. Intraclass Correlation Coefficient (ICC) of each item of the ÖMSQ-12-J

\begin{tabular}{lc}
\hline Items (No. Description) & ICC \\
& $(95 \%$ CIs) \\
\hline 1. When did your current pain or problem start? & 0.99 \\
Check one. & $(0.99-0.99)$ \\
2. Rate how much of a burden it is to perform all & 0.90 \\
the things you need to do in a normal day. & $(0.83-0.94)$ \\
3. For the last 2-3 days, rate on average how & 0.84 \\
bothersome your pain or problem is. & $(0.73-0.90)$ \\
4. For the last 2-3 days, what percentage of the & 0.75 \\
day do you notice your pain or problem? & $(0.60-0.85)$ \\
5. During the past 2-3 days, rate how tense or & 0.88 \\
anxious you have felt. & $(0.80-0.93)$ \\
6. During the past 2-3 days, rate how 'depressed' & 0.88 \\
or 'down' you have felt. & $(0.81-0.93)$ \\
7. What do you think is the risk that your current & 0.79 \\
pain or problem will not improve? & $(0.66-0.88)$ \\
8. Think of your life; rate how satisfied you are & 0.77 \\
with your current situation. & $(0.54-0.88)$ \\
9. Physical activity makes my pain or problem & 0.76 \\
worse. & $(0.61-0.85)$ \\
10. I should not do my normal daily routine or & 0.71 \\
work with my present pain or problem. & $(0.54-0.83)$ \\
11. I can walk for an hour or participate in my & 0.86 \\
normal light recreational or sporting activities. & $(0.77-0.92)$ \\
12. I manage my daily routine and social activities & 0.87 \\
(e.g. Shopping or transport or see friends). & $(0.78-0.93)$ \\
\hline
\end{tabular}

the recognized development process - the ÖMPQ and OMPQ-10, is that an adequate intersession reliability was detected for the ÖMSQ-12-J in individuals with a variety of symptom locations. The ÖMSQ-12-J also overcomes the three major recognized shortcomings present in the original-ÖMPQ and ÖMPQ-10: a focus on LBP items predicting work and pain outcomes rather than broader considerations of musculoskeletal items predicting problems and functional outcomes in the general population $^{31)}$. 
The limitations and weaknesses of the current study are firstly that there is no longitudinal component that specifically determines the predictive capacity and validity of the ÖMSQ-12-J. However, this critically required component of research cannot itself be undertaken until a validly translated, culturally adapted and reliable Japanese version tool is available. Consequently, this subsequent stage was beyond the scope of the current study. Secondly, there were no participants with acute symptoms ( $<1$ week) and most had subacute or chronic symptoms ( $>3$ months). The minimum impact of a natural acute stage recovery in this study population might have been associated with the high consistency of responses. The ÖMSQ-12-J would potentially also be used as a prognostic tool for individuals with acute symptoms but further investigations will be required for acute symptom populations in order to fully investigate the clinical capacity of the ÖMSQ-12-J and its intersession reliability in all symptom duration circumstances. Similarly, longitudinal studies that will enable a comparison of baseline ÖMSQ-12-J scores and recovery time in order to determine risk cut-off values. The third limitation is that the results were derived from a sample of convenience as a pilot investigatory study was undertaken with a focus on the provision of a tool that is sound in the translation and cultural adaptation process. Therefore, a more robust sampling method will be required to obtain definitive results from a larger population.

In conclusion, a Japanese version of the ÖMSQ-12 has been developed through translation and cross-cultural adaptation. The findings show good practicality and moderate to strong intersession reliability. This study completes the critical initial stage of making this tool available for use and research within a Japanese language and cultural setting. This serves as completion of the preliminary phase and will be a foundation for further investigations that can develop the prognostic cut-off scores, reliability in different stages of recovery and determination of the effectiveness of this tool within a prognostic approach for musculoskeletal disorders. In turn, this is expected to enhance treatment effects and reduce both financial and social burdens.

\section{ACKNOWLEDGEMENTS}

The authors wish to acknowledge Mr. Katsumi Goto and Ms. Ai Nagayasu for forward-translation and Mr. Hiroyuki Hasegawa and Mr. Tadahiro Okutani for backward-translation.

\section{REFERENCES}

1) March L, Smith EU, Hoy DG, et al.: Burden of disability due to musculoskeletal (MSK) disorders. Best Pract Res Clin Rheumatol, 2014, 28: 353-366. [Medline] [CrossRef]

2) Brooks PM: The burden of musculoskeletal disease - a global perspective. Clin Rheumatol, 2006, 25: 778-781. [Medline] [CrossRef]

3) Foster NE, Hill JC, O'Sullivan P, et al.: Stratified models of care. Best Pract Res Clin Rheumatol, 2013, 27: 649-661. [Medline] [CrossRef]

4) Foster NE, Dziedzic KS, van der Windt DA, et al.: Research priorities for non-pharmacological therapies for common musculoskeletal problems: nationally and internationally agreed recommendations. BMC Musculoskelet Disord, 2009, 10: 3. [Medline] [CrossRef]

5) Linton SJ, Halldén K: Can we screen for problematic back pain? A screening questionnaire for predicting outcome in acute and subacute back pain. Clin J Pain, 1998, 14: 209-215. [Medline] [CrossRef]

6) Kendall N, Linton S, Main C: Guide to assessing psychosocial yellow flags in acute low back pain: risk factors for long-term disability and work loss. Wellington: Accident Compensation Commission, 1997.

7) Linton SJ, Boersma K: Early identification of patients at risk of developing a persistent back problem: the predictive validity of the Orebro Musculoskeletal Pain Questionnaire. Clin J Pain, 2003, 19: 80-86. [Medline] [CrossRef]

8) Hill JC, Dunn KM, Lewis M, et al.: A primary care back pain screening tool: identifying patient subgroups for initial treatment. Arthritis Rheum, 2008, 59: 632-641. [Medline] [CrossRef]

9) Murphy SE, Blake C, Power CK, et al.: Comparison of a stratified group intervention (STarT Back) with usual group care in patients with low back pain: a nonrandomized cntrolled trial. Spine, 2016, 41: 645-652. [Medline] [CrossRef]

10) Hill JC, Whitehurst DG, Lewis M, et al.: Comparison of stratified primary care management for low back pain with current best practice (STarT Back): a randomised controlled trial. Lancet, 2011, 378: 1560-1571. [Medline] [CrossRef]

11) Hazard RG, Haugh LD, Reid S, et al.: Early prediction of chronic disability after occupational low back injury. Spine, 1996, 21: 945-951. [Medline] [CrossRef]

12) Gabel CP, Burkett B, Melloh M: The shortened Örebro Musculoskeletal Screening Questionnaire: evaluation in a work-injured population. Man Ther, 2013, 18: 378-385. [Medline] [CrossRef]

13) Gabel CP, Melloh M, Burkett B, et al.: The Örebro Musculoskeletal Screening Questionnaire: validation of a modified primary care musculoskeletal screening tool in an acute work injured population. Man Ther, 2012, 17: 554-565. [Medline] [CrossRef]

14) Gabel CP, Melloh M, Yelland M, et al.: Predictive ability of a modified Örebro Musculoskeletal Pain Questionnaire in an acute/subacute low back pain working population. Eur Spine J, 2011, 20: 449-457. [Medline] [CrossRef]

15) Westman A, Linton SJ, Ohrvik J, et al.: Do psychosocial factors predict disability and health at a 3-year follow-up for patients with non-acute musculoskeletal pain? A validation of the Orebro Musculoskeletal Pain Screening Questionnaire. Eur J Pain, 2008, 12: 641-649. [Medline] [CrossRef]

16) Sattelmayer M, Lorenz T, Röder C, et al.: Predictive value of the Acute Low Back Pain Screening Questionnaire and the Örebro Musculoskeletal Pain Screening Questionnaire for persisting problems. Eur Spine J, 2012, 21: S773-S784. [Medline] [CrossRef]

17) Margison DA, French DJ: Predicting treatment failure in the subacute injury phase using the Orebro Musculoskeletal Pain Questionnaire: an observational 
prospective study in a workers' compensation system. J Occup Environ Med, 2007, 49: 59-67. [Medline] [CrossRef]

18) Gabel P, Burkett B, Yelland M: Balancing fidelity and practicality in short version musculoskeletal patient reported outcome measures. Phys Ther Rev, 2009, 14: 221-225. [CrossRef]

19) Nicholas MK, Linton SJ, Watson PJ, et al. "Decade of the Flags" Working Group: Early identification and management of psychological risk factors ("yellow flags") in patients with low back pain: a reappraisal. Phys Ther, 2011, 91: 737-753. [Medline] [CrossRef]

20) Beaton DE, Bombardier C, Guillemin F, et al.: Guidelines for the process of cross-cultural adaptation of self-report measures. Spine, 2000, 25: 3186-3191. [Medline] [CrossRef]

21) Takasaki H, Saiki T, Iwasada Y: McKenzie therapists adhere more to evidence-based guidelines and have a more biopsychosocial perspective on the management of patients with low back pain than general physical therapists in Japan. Open J Ther Rehabil, 2014, 2: 173-181. [CrossRef]

22) Takasaki H, Iwasada Y, May S: Attitude towards the use of mechanical diagnosis and therapy and reliability of classification extremity problems by credentialed therapists. J Chiropr Med, 2015, 14: 32-38. [Medline] [CrossRef]

23) Takasaki H: Agreement of mechanical diagnosis and therapy classification in people with extremity conditions. Phys Ther, 2016, 96: 1525-1532. [Medline] [CrossRef]

24) Takasaki H, Okuyama K, Rosedale R: Inter-examiner classification reliability of Mechanical Diagnosis and Therapy for extremity problems-systematic review. Musculoskelet Sci Pract, 2017, 27: 78-84.

25) Shrout PE, Fleiss JL: Intraclass correlations: uses in assessing rater reliability. Psychol Bull, 1979, 86: 420-428. [Medline] [CrossRef]

26) Bartko JJ: The intraclass correlation coefficient as a measure of reliability. Psychol Rep, 1966, 19: 3-11. [Medline] [CrossRef]

27) Bonett DG: Sample size requirements for estimating intraclass correlations with desired precision. Stat Med, 2002, 21: 1331-1335. [Medline] [CrossRef]

28) Spadoni GF, Stratford PW, Solomon PE, et al.: The evaluation of change in pain intensity: a comparison of the P4 and single-item numeric pain rating scales. J Orthop Sports Phys Ther, 2004, 34: 187-193. [Medline] [CrossRef]

29) Andresen EM: Criteria for assessing the tools of disability outcomes research. Arch Phys Med Rehabil, 2000, 81: S15-S20. [Medline] [CrossRef]

30) Fuhro FF, Fagundes FR, Manzoni AC, et al.: Örebro Musculoskeletal Pain Screening Questionnaire short-form and STarT back screening tool: correlation and agreement analysis. Spine, 2016, 41: E931-E936. [Medline] [CrossRef]

31) Gabel CP, Osborne J, Burkett B, et al.: Development of a short form of the Örebro Musculoskeletal Pain Screening Questionnaire. Spine (Phila Pa 1976) 2011; 36: 1891-1895. Spine, 2015, 40: E913. [Medline] [CrossRef]

\section{Appendix 1.}

Summary of reasons and/or comments for developing a consensus draft through forward-translations

\section{Original expression*}

When did your current pain or problem start? Check one.

Not at all

Extremely

What do you think is the risk that your current pain or problem will not improve?

\section{Expression of the consensus draft*}

現在の痛みや症状が始まっ たのはいつからですか?

全く・・・ない

極めて・・・

現在の症状が改善しない可 能性がどの程度あると思い ますか?

\section{Reasons and/or comments}

'Problem' may be misunderstood by ordinal people and thus 'problem' was translated into '症状', indicating 'symptom'.

Verbs have been added to enhance clarity of meanings.

'Risk' may be too strong meaning in Japanese and thus 'risk' was translated into '可能性', indicating 'possibility'.

*The discussion point has been underlined.

\section{Appendix 2.}

Japanese version of the 12-item Örebro Musculoskeletal Screening Questionnaire

1) 現在の痛みや症状が始まったのはいつからですか?
$\square 0-1$ 週[1]
$\square 1-2$ 週[2]
$\square 3-4$ 週[3]
$\square 4-5$ 週[4]
$\square 6-8$ 週[5]
$\square 9-11$ 週[6] $\square 3-6$ ケ月[7] $\square 6-9$ ケ月 [8]
$\square 9-12$ ケ月 [9]
$\square 1$ 年以上 $[10]$

2) 普段の生活に必要なことを全てこなすのにどの程度の負担を感じますか?

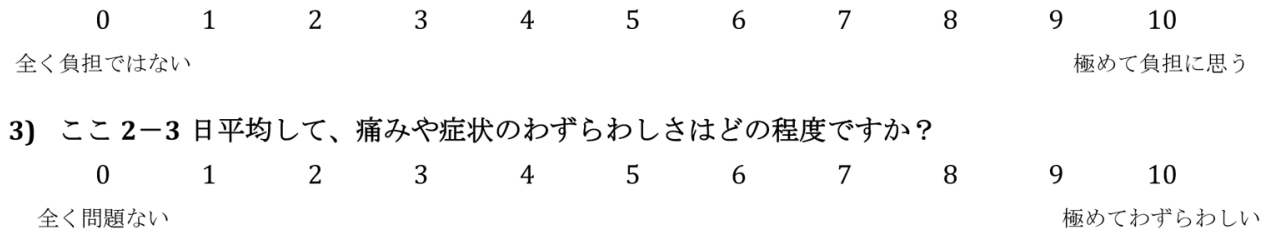

4) ここ 2-3 日、痛みや症状が気になるのは一日のうちで何パーセント程度ですか?

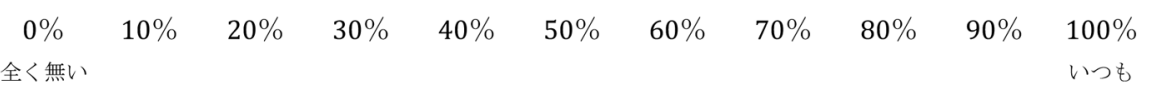


あなたの考えや気持ちについてお聞きします

5) ここ 2-3 日、どの程度気が張り詰めていたり、不安に感じますか?

$\begin{array}{cccccccccc}0 & 1 & 2 & 3 & 4 & 5 & 6 & 7 & 8 & 9 \\ \text { 全くそう感じない } & & & & & & & & & \text { 極めてそう感じる }\end{array}$

6) ここ 2-3 日、どの程度気持ちが沈んだり、憂稂に感じますか?

$\begin{array}{cccccccccc}0 & 1 & 2 & 3 & 4 & 5 & 6 & 7 & 8 & 9 \begin{array}{c}10 \\ \text { 全くそう感しない }\end{array} \\ & & & & & & & & & \end{array}$

7) 現在の症状が改善しない可能性がどの程度あると思いますか?

$\begin{array}{ccccccccccc}0 & 1 & 2 & 3 & 4 & 5 & 6 & 7 & 8 & 9 & 10 \\ \text { 全くない } & & & & & & & & & \text { 加ある }\end{array}$

8) あなたの生活を考えてみてください。どの程度現在の状況に満足していますか? [10-x]

$\begin{array}{cccccccccc}0 & 1 & 2 & 3 & 4 & 5 & 6 & 7 & 8 & 9 \\ \text { 全く満足していない } & & & & & & & & 100 \% \text { 満足している }\end{array}$

以下の二つは、どの程度あなたに当てはまりますか?

9) 身体活動は症状を悪化させる

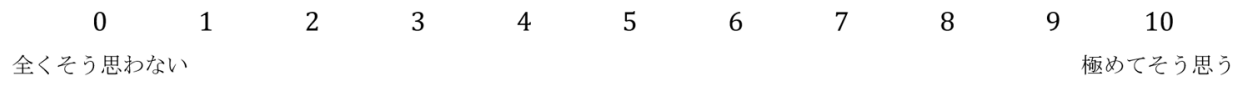

10) 現在の症状が有るまま、日常生活や仕事をすべきではない。

$\begin{array}{ccccccccccc}0 & 1 & 2 & 3 & 4 & 5 & 6 & 7 & 8 & 9 & 10 \\ \text { 全くそう思わない } & & & & & & & & & & \\ \text { 極めてそう思う }\end{array}$

どの程度体を動かせるかお聞きします

11) 1 時間の歩行、普段の軽い娛楽活動やスポーツ [10-x]

$\begin{array}{cccccccccccc}0 & 1 & 2 & 3 & 4 & 5 & 6 & 7 & 8 & 9 & 10 \\ \text { 全く出来ない } & & & & & & & & & & \text { 正常に出来る }\end{array}$

12）日常生活や社会活動（例. 買い物、移動、友人と会うこと）[10-x]
0
全く出来ない
45
67
$8 \quad 9$
10
正常に出来る 